\title{
STUDIES OF GONOCOCCAL INFECTION. I. A STUDY OF THE MODE OF DESTRUCTION OF THE GONOCOCCUS IN VITRO ${ }^{1}$
}

\author{
By WESLEY W. SPINK AND CHESTER S. KEEFER \\ (From the Thorndike Memorial Laboratory, Second and Fourth Medical Services (Harvard), \\ Boston City Hospital, and the Department of Medicine, Harvard Medical School, Boston)
}

(Received for publication October 7, 1936)

At the present time, little is known concerning the development of local or general immunity in patients with gonococcal infections. It is universally recognized that local infections are notoriously chronic and that repeated infections of the same individual are common. The study of the immune mechanism in animals has not been very satisfactory since it is an extremely difficult matter to establish a gonococcal infection in ordinary laboratory animals. It did not seem unreasonable to suppose that more information could be obtained concerning the mechanism of immunity from a study of several serological reactions that appear during the course of the natural infection in man. We have studied, therefore, various antibodies in the blood of patients with different types of gonococcal infection, viz., the complement-fixing antibodies, agglutinins, precipitins, and the bactericidal power of defibrinated whole blood upon the gonococcus. We have found a study of the bactericidal power of whole blood most serviceable, and at this time we present a detailed discussion of its action, together with an analysis of the action of the circulating leukocytes and serum, upon the gonococcus. The results of this and the other tests upon a series of patients with gonococcal infections and normal controls are presented in the second paper.

\section{METHODS}

The bactericidal action of whole defibrinated blood, serum, or plasma was determined by the method of Todd as used by us (1) in studying the hemolytic streptococcus. To $0.5 \mathrm{cc}$. of whole defibrinated blood, serum, or plasma, in small pyrex tubes, varying dilutions of an 18-hour suspension of gonococci in ascitic fluid broth were added. The number of organisms in each tube was determined by the plating of $1 \mathrm{cc}$. of the con-

1 This investigation was aided, in part, by a grant from the Milton Fund and Clark Bequest. tents of tubes $10^{-6}$ and $10^{-7}$. The tubes were sealed in a gas-oxygen flame and then rotated, in a box, for 36 to 48 hours in an incubator at $37.5^{\circ}$ C. The tubes were then opened and the contents were cultured to determine the presence of living organisms.

Thirty-six strains of gonococci isolated from active cases of gonorrhea have been studied in this manner. They were obtained from urethral and cervical exudates, synovial fluid, tendon sheaths, conjunctivae, and the circulating blood. The strains were grown on horse blood agar plates with a $\mathrm{pH}$ of 7.8 and sub-cultured every 3 days. The identity of the organisms as gonococci was proved by agglutination reactions with a polyvalent antigonococcal serum, and by sugar fermentation tests.

The action of the leukocytes upon the gonococcus was investigated in two ways. First, quantitative phagocytic studies were made on the blood of patients with gonococcal arthritis, and of normal controls. The procedure was to add $0.1 \mathrm{cc}$. of an 18-hour ascitic fluid broth culture of gonococci to $0.5 \mathrm{cc}$. of whole defibrinated blood in small pyrex tubes. After sealing the tubes, they were rotated in the incubator for 15 minutes to 4 hours. It was found that 15 minutes was the optimal time for maximal phagocytosis to take place. Smears were made and stained with Wright's stain. Fifty polymorphonuclear leukocytes were counted, and the number of cells containing organisms was noted. The degree of phagocytosis was compared with the bactericidal action of whole blood on the same suspension of organisms. The second method was to remove the plasma from whole defibrinated blood and wash the cells 4 times with 0.85 per cent salt solution. One-tenth of a cubic centimeter of a suspension of gonococci was added to $0.25 \mathrm{cc}$. of cells suspended in $0.25 \mathrm{cc}$. of salt solution in pyrex tubes. The tubes were sealed and rotated for 15 minutes, and then opened to determine the 
presence of living organisms and the degree of phagocytosis.

\section{RESULTS}

Bactericidal action of whole defibrinated blood, serum and plasma

The results of 33 observations on the bactericidal action of the whole defibrinated blood and of serum or plasma alone are presented in Table I. Thirteen different strains of gonococci were used. One specimen of blood was obtained from each of 13 patients with various types of gonococcal lesions and 2 normal controls. It is to be noted that equivalent amounts of serum had essentially the same killing power as whole, defibrinated blood. Tests were also done with plasma to determine whether it had the same killing power as serum or whole blood. An examination of
Wright's stained smears made from the blood in which there was growth of organisms revealed that most of the polymorphonuclear leukocytes contained gonococci. However, similar smears examined from the blood in the tubes in which there was no growth failed to show either extracellular or intracellular organisms. In short, it would appear that when the gonococcus was killed by the blood, it underwent complete lysis.

\section{Bactericidal action of whole defibrinated blood, plasma and heated plasma}

It has been indicated already that the killing power of whole defibrinated blood for the gonococcus is essentially the same as that of plasma or serum. If this bacteriolytic action on the gonococcus is due to the combined action of anti-

TABLE I

Comparison of bactericidal power of whole defibrinated blood, serum, and plasma*

(Each row represents a tenfold dilution of the gonococcus)

\begin{tabular}{|c|c|c|c|c|c|c|c|c|c|c|c|c|c|c|c|c|c|c|c|c|c|c|c|c|}
\hline \multirow{2}{*}{$\begin{array}{c}\text { Obser- } \\
\text { vation } \\
\text { num- } \\
\text { ber }\end{array}$} & \multirow{2}{*}{\begin{tabular}{|} 
Patient \\
number
\end{tabular}} & & \multicolumn{7}{|c|}{ Whole defibrinated blood } & \multicolumn{7}{|c|}{ Serum } & \multicolumn{7}{|c|}{ Plasma } & \multirow{2}{*}{$\begin{array}{l}\text { Number } \\
\text { of } \\
\text { organisms }\end{array}$} \\
\hline & & & $10^{-1}$ & $10 \rightarrow$ & $10-2$ & $10-4$ & $10-6$ & $10-8$ & $10-7$ & $10^{-1}$ & $10-2$ & $10^{-3}$ & $\left|10^{-4}\right|$ & $10^{-6}$ & $\mid 10^{-9}$ & $10^{-7}$ & $\mid 10^{-1}$ & $10-3$ & $10^{-3}$ & $10^{-4}$ & $10^{-6}$ & $10^{-6}$ & $10^{-7}$ & \\
\hline $\begin{array}{r}1 \\
2 \\
3 \\
4 \\
5 \\
6 \\
7 \\
8 \\
9 \\
10 \\
11 \\
12 \\
13 \\
14 \\
15 \\
16 \\
17 \\
18 \\
19 \\
20 \\
21 \\
22 \\
23 \\
24 \\
25 \\
26 \\
27 \\
28 \\
29 \\
30 \\
31 \\
32 \\
33\end{array}$ & $\begin{array}{r}7 \\
8 \\
9 \\
10 \\
11 \\
12 \\
13\end{array}$ & $\begin{array}{r}1 \\
2 \\
3 \\
4 \\
5 \\
6 \\
6 \\
13 \\
7 \\
8 \\
7 \\
8 \\
6 \\
9 \\
10 \\
11 \\
12 \\
7 \\
13 \\
13 \\
13 \\
7 \\
12 \\
10 \\
99 \\
8 \\
6 \\
13 \\
1 \\
2 \\
12 \\
7 \\
1\end{array}$ & $\begin{array}{l}+ \\
+ \\
+ \\
+ \\
+ \\
+ \\
+ \\
+ \\
+ \\
+ \\
0 \\
+ \\
0 \\
0 \\
0 \\
0 \\
0 \\
0 \\
0 \\
0 \\
0 \\
0 \\
0 \\
0 \\
+ \\
+ \\
+ \\
+ \\
+ \\
+ \\
+ \\
0 \\
0\end{array}$ & $\begin{array}{l}+ \\
+ \\
0 \\
+ \\
+ \\
0 \\
0 \\
0 \\
0 \\
0 \\
0 \\
+ \\
0 \\
0 \\
0 \\
0 \\
0 \\
0 \\
0 \\
0 \\
0 \\
0 \\
0 \\
0 \\
+ \\
+ \\
+ \\
+ \\
+ \\
+ \\
+ \\
0\end{array}$ & $\begin{array}{l}0 \\
0 \\
0 \\
0 \\
+ \\
0 \\
0 \\
0 \\
0 \\
0 \\
0 \\
+ \\
0 \\
0 \\
0 \\
0 \\
0 \\
0 \\
0 \\
0 \\
0 \\
0 \\
0\end{array}$ & $\begin{array}{l}0 \\
0 \\
0 \\
0 \\
0 \\
0 \\
0 \\
0 \\
0 \\
0 \\
0 \\
0 \\
0 \\
0 \\
0 \\
0 \\
0 \\
0 \\
0 \\
0 \\
0 \\
0 \\
0 \\
0 \\
+ \\
+ \\
+ \\
+ \\
+ \\
0 \\
0\end{array}$ & $\begin{array}{l}0 \\
0 \\
0 \\
0 \\
0 \\
0 \\
0 \\
0 \\
0 \\
0 \\
0 \\
0 \\
0 \\
0 \\
0 \\
0 \\
0 \\
0 \\
0 \\
0 \\
0 \\
0 \\
0 \\
0 \\
+ \\
+ \\
+ \\
+ \\
+ \\
+\end{array}$ & $\begin{array}{l}0 \\
0 \\
0 \\
0 \\
0 \\
0 \\
0 \\
0 \\
0 \\
0 \\
0 \\
0 \\
0 \\
0 \\
0 \\
0 \\
0 \\
0 \\
0 \\
0 \\
0 \\
0 \\
0 \\
0 \\
+ \\
+ \\
+ \\
+ \\
+ \\
0 \\
0 \\
0\end{array}$ & $\begin{array}{l}0 \\
0 \\
0 \\
0 \\
0 \\
0 \\
0 \\
0 \\
0 \\
0 \\
0 \\
0 \\
0 \\
0 \\
0 \\
0 \\
0\end{array}$ & $\begin{array}{l}0 \\
0 \\
0 \\
+ \\
+ \\
0 \\
+ \\
0 \\
0 \\
0 \\
+ \\
+ \\
+ \\
+ \\
0 \\
0 \\
0 \\
0 \\
0\end{array}$ & $\begin{array}{l}0 \\
0 \\
0 \\
0 \\
0 \\
0 \\
+ \\
0 \\
0 \\
0\end{array}$ & $\begin{array}{l}0 \\
0 \\
0 \\
0 \\
0 \\
0 \\
+ \\
0 \\
0 \\
0 \\
0 \\
0 \\
0 \\
0 \\
0 \\
0 \\
0 \\
0\end{array}$ & $\begin{array}{l}0 \\
0 \\
0 \\
0 \\
0 \\
0 \\
0 \\
0 \\
0 \\
0 \\
0 \\
0 \\
0 \\
0 \\
0 \\
0 \\
0 \\
0\end{array}$ & $\begin{array}{l}0 \\
0 \\
0 \\
0 \\
0 \\
0 \\
0 \\
0 \\
0 \\
0 \\
0 \\
0 \\
0 \\
0 \\
0 \\
0 \\
0 \\
0 \\
0\end{array}$ & $\begin{array}{l}0 \\
0 \\
0 \\
0 \\
0 \\
0 \\
0 \\
0 \\
0 \\
0 \\
0 \\
0 \\
0 \\
0 \\
0 \\
0 \\
0 \\
0 \\
0\end{array}$ & $\begin{array}{l}\mathbf{0} \\
\mathbf{0} \\
\mathbf{0} \\
\mathbf{0} \\
\mathbf{0} \\
\mathbf{0} \\
\mathbf{0} \\
\mathbf{0} \\
\mathbf{0} \\
\mathbf{0}\end{array}$ & $\begin{array}{l}+ \\
+ \\
+ \\
+ \\
+\end{array}$ & $\begin{array}{l}+ \\
+ \\
+ \\
+ \\
+\end{array}$ & $\begin{array}{l}+ \\
+ \\
+ \\
+ \\
+\end{array}$ & $\begin{array}{l}+ \\
+ \\
+ \\
+ \\
+\end{array}$ & $\begin{array}{l}+ \\
+ \\
+ \\
+ \\
+\end{array}$ & $\begin{array}{l}+ \\
+ \\
+ \\
+\end{array}$ & $\begin{array}{l}0 \\
0 \\
0 \\
0 \\
0\end{array}$ & $\begin{array}{l}10^{-6}=4 \\
? \\
10^{-6}=4 \\
10^{-6}=3 \\
10^{-7}=12 \\
10^{-6}=3 \\
10^{-6}=2 \\
10^{-6}=2 \\
10^{-6}=2 \\
10^{-6}=4 \\
10^{-6}=4 \\
10^{-6}=4 \\
10^{-6}=4 \\
10^{-6}=4 \\
10^{-6}=4 \\
10^{-7}=4 \\
10^{-6}=10 \\
10^{-7}=3 \\
10^{-7}=3 \\
10^{-6}=8 \\
10^{-6}=2 \\
10^{-6}=10 \\
10^{-6}=2 \\
10^{-7}=5\end{array}$ \\
\hline
\end{tabular}

$*+$ growth

$0=$ no growth. 
TABLE II

Comparison of bactericidal power of whole defibrinated blood, unheated plasma, and heated plasma*

\begin{tabular}{|c|c|c|c|c|c|c|c|c|c|c|c|c|c|c|c|c|c|c|c|c|c|c|c|c|}
\hline \multirow{2}{*}{$\begin{array}{c}\text { Observa- } \\
\text { tion } \\
\text { number }\end{array}$} & \multirow{2}{*}{$\begin{array}{c}\text { Patient } \\
\text { num- } \\
\text { ber }\end{array}$} & \multirow{2}{*}{$\underset{\substack{\text { Strain } \\
\text { ber }}}{\text { ber }}$} & \multicolumn{7}{|c|}{ Whole blood } & \multicolumn{7}{|c|}{ Unheated plasma } & \multicolumn{7}{|c|}{ Heated plasma } & \multirow{2}{*}{$\begin{array}{l}\text { Num- } \\
\text { ber of } \\
\text { organ- } \\
\text { isms }\end{array}$} \\
\hline & & & $10^{-1}$ & $10^{-2}$ & $10-2$ & $10-4$ & $10^{-8}$ & $10^{-6}$ & $10-7$ & $10^{-1}$ & $10-2$ & $10^{-2}$ & $10^{-4}$ & $10^{-8}$ & $10-8$ & $10^{-7}$ & $10^{-1}$ & $10^{-2}$ & $10^{-3}$ & $10-4$ & $10^{-8}$ & $10^{-6}$ & $10^{-7}$ & \\
\hline 1 & 5 & 5 & + & + & 0 & 0 & 0 & 0 & 0 & $\mathbf{0}$ & 0 & 0 & 0 & 0 & $\mathbf{0}$ & $\mathbf{0}$ & + & + & + & + & + & 0 & 0 & $10^{-7}$ \\
\hline 2 & 4 & 4 & + & + & + & 0 & 0 & 0 & 0 & + & + & + & 0 & 0 & 0 & 0 & + & + & + & + & + & + & + & ${ }_{9}^{10^{-7}}$ \\
\hline
\end{tabular}

$*+=$ growth.

$0=$ no growth.

body and complement in serum or plasma, then heating either one to inactivate complement should result in reducing the killing power. Table II shows the results of heating plasma at $56^{\circ} \mathrm{C}$. for 30 minutes in a water bath and comparing its bactericidal action with that of unheated plasma and whole blood. Heated plasma had practically no bactericidal action on the gonococcus. Heated plasma added to washed cells also resulted in the death of no organisms.

It was conceivable from these observations that the difference between the action of heated and unheated plasma was not due to the inactivation of complement but to the fact that unheated plasma was a poor culture medium whereas heated plasma was a good one. However, from the following experiments, we demonstrated that unheated plasma killed gonococci when antibodies were present, and heated plasma failed to kill them owing to the inactivation of complement.

The first experiment showed that complement was necessary for bactericidal action to take place. We obtained a polyvalent antigonococcal horse serum (Parke Davis) which agglutinated all strains of gonococci used. This immune serum did not contain complement. As a result, it is seen in Table III that the serum alone had no bactericidal power. However, when $0.1 \mathrm{cc}$. of fresh, undiluted human serum was added to $0.4 \mathrm{cc}$. of this immune serum, excellent bactericidal action resulted. It is seen further that the same amount of fresh serum $(0.1 \mathrm{cc}$.) diluted to $0.5 \mathrm{cc}$. did not kill the organisms. Only when the immune serum was activated by fresh serum containing complement did bactericidal action result.

To study further the bactericidal action in human plasma, samples were obtained that possessed killing power, and they were compared with those
TABLE III

The bactericidal action of immune serum with and without the addition of fresh human serum (complement) *

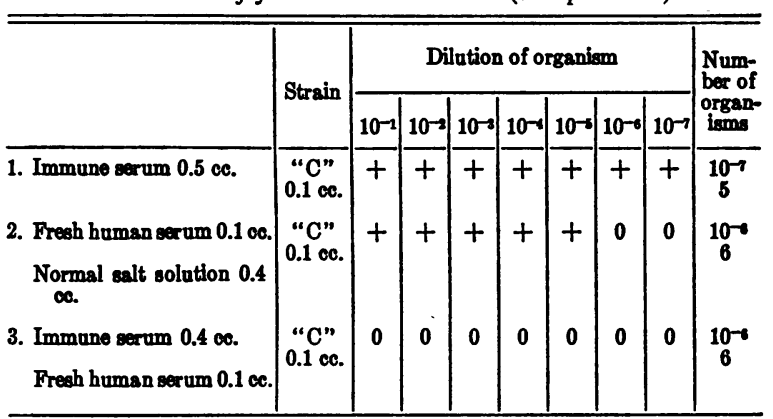

$*+=$ growth.

$0=$ no growth.

showing no killing power. The results are recorded in Table IV. Unheated plasma "W" was capable of destroying the " $\mathrm{C}$ " strain of gonococcus, whereas the heated serum had lost this capacity. To test whether heating the serum destroyed the antibody, immune serum was added to the heated serum; no killing of the organism resulted. The heated serum was then reinactivated by the addition of fresh serum from a normal individual, and the killing power was restored in part. From this experiment, it would appear that heating a plasma that was capable of killing gonococci inactivated complement and did not destroy antibody. The addition of immune serum to heated serum was ineffective in restoring bactericidal power, whereas the addition of fresh serum (complement) restored it in part.

In the case of serum " $K$ " which contained no antibodies against organisms " $\mathrm{C}$ " it was found that the addition of antibody (immune serum) caused killing when it was added to unheated serum, but no killing was observed when it was added to heated serum. The death of the organisms was produced when immune serum was 
TABLE IV

The bactericidal action of heated and unheated human plasma with and without antibodies*

\begin{tabular}{|c|c|c|c|c|c|c|c|c|}
\hline \multirow{2}{*}{ Observations } & \multicolumn{7}{|c|}{ Dilution of organisms } & \multirow{2}{*}{ 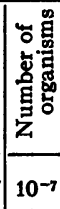 } \\
\hline & $10^{-1}$ & $10^{-2}$ & $10^{-3}$ & $10^{-4}$ & $10^{-5}$ & $10^{-6}$ & $10-7$ & \\
\hline $\begin{array}{l}\text { Serum "W," unheated } 0.5 \\
\text { cc. } \\
\text { Organism "C" } 0.1 \mathrm{cc} .\end{array}$ & + & $\mathbf{0}$ & 0 & $\mathbf{0}$ & 0 & 0 & 0 & 5 \\
\hline $\begin{array}{l}\text { Serum " W" heated } 0.5 \mathrm{cc} \text {. } \\
\text { Organism " } \mathrm{C} \text { " } 0.1 \mathrm{cc} .\end{array}$ & + & + & + & + & + & + & $\mathbf{0}$ & 5 \\
\hline $\begin{array}{l}\text { Serum "W" } \mathrm{W} \text { " heated } 0.4 \mathrm{cc} . \\
\text { Organism "C" } 0.1 \mathrm{cc} \text { and } \\
\text { immune serum } 0.1 \mathrm{cc} \text {. }\end{array}$ & + & + & + & + & + & + & $\mathbf{0}$ & 5 \\
\hline $\begin{array}{l}\text { Serum "W" heated } 0.4 \mathrm{cc} \text {. } \\
\text { Organism "c" } 0.1 \mathrm{cc} \text { and } \\
\text { fresh serum " } \mathrm{S} \text { " } 0.1 \mathrm{cc} \text {. }\end{array}$ & + & + & + & $\mathbf{0}$ & $\mathbf{0}$ & $\mathbf{0}$ & $\mathbf{0}$ & 5 \\
\hline $\begin{array}{l}\text { Fresh serum "S" } 0.5 \mathrm{cc} \text {. } \\
\text { and organism " } \mathrm{C} " 0.1 \mathrm{cc} \text {. }\end{array}$ & + & + & + & + & + & + & + & 5 \\
\hline $\begin{array}{c}\text { Immune serum } 0.5 \mathrm{cc} \text {. and } \\
\text { organism " } \mathrm{C} " 0.1 \mathrm{cc} \text {. }\end{array}$ & + & + & + & + & + & + & + & 5 \\
\hline $\begin{array}{l}\text { Serum “D." unheated } 0.5 \\
\text { cc. } \\
\text { Organism " C" } 0.1 \mathrm{cc} .\end{array}$ & $\mathbf{0}$ & $\mathbf{0}$ & $\mathbf{0}$ & $\mathbf{0}$ & $\mathbf{0}$ & $\mathbf{0}$ & $\mathbf{0}$ & 2 \\
\hline 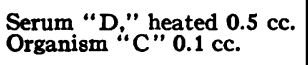 & + & + & + & + & + & + & + & 2 \\
\hline $\begin{array}{l}\text { Fresh serum "S" } 0.5 \mathrm{cc} \text {. } \\
\text { and organism "C" } 0.1 \mathrm{cc} \text {. }\end{array}$ & + & + & + & + & + & + & + & 2 \\
\hline $\begin{array}{l}\text { Serum "D," heated } 0.5 \mathrm{cc} \text {. } \\
\text { Fresh serum "S" } 0.5 \mathrm{cc} \text {. } \\
\text { and organism "C" } 0.1 \mathrm{cc} .\end{array}$ & + & 0 & 0 & 0 & 0 & 0 & 0 & 2 \\
\hline $\begin{array}{l}\text { Serum “ } \mathrm{K}, " \text { unheated } 0.5 \\
\text { cc. } \\
\text { Organism "C" } 0.1 \mathrm{cc} .\end{array}$ & + & + & + & + & + & + & + & 4 \\
\hline 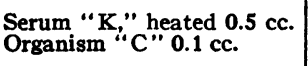 & + & + & + & + & + & + & + & 4 \\
\hline $\begin{array}{l}\text { Serum " } \mathrm{K} \text { "“ heated } 0.5 \mathrm{cc} \text {. } \\
\text { Organism " } \mathrm{C} \text { " } 0.1 \mathrm{cc} \text { and } \\
\text { immune serum } 0.1 \mathrm{cc} \text {. }\end{array}$ & + & + & + & + & + & + & + & 4 \\
\hline $\begin{array}{l}\text { Serum " } K \text {," heated } 0.25 \mathrm{cc} \text {. } \\
\text { Immune serum } 0.1 \mathrm{cc} \text {. } \\
\text { organism "C" } 0.1 \mathrm{cc} \text {. and } \\
\text { fresh serum " } \mathrm{S} \text { " } 0.25 \mathrm{cc} \text {. }\end{array}$ & + & + & 0 & 0 & 0 & 0 & 0 & 4 \\
\hline $\begin{array}{l}\text { Serum “K." "unheated } 0.5 \mathrm{cc} \text {. } \\
\text { Immune serum } 0.1 \mathrm{cc} . \\
\text { Organism "C" } 0.1 \mathrm{cc} .\end{array}$ & + & 0 & 0 & 0 & 0 & 0 & 0 & 4 \\
\hline
\end{tabular}

$*+=$ growth.

$0=$ no growth.

added to heated serum which had been reactivated by fresh serum. The same results were obtained with another serum " $D$ " which was obtained from a patient with gonococcal arthritis.

It would appear to be established that the gonococcus is killed in vitro by lysis. Both antibody and complement are necessary for this action.

\section{Bactericidal action of whole defibrinated blood and washed cells suspended in saline}

It has been recognized for many years that the gonococcus is actively phagocyted by polymorpho- nuclear leukocytes. Whether or not this indicates a method of destruction has remained in dispute. By a series of experiments we set out to determine the relative importance of the cells in the destruction of the gonococcus in vitro. In Table $\mathrm{V}$, we present 5 observations comparing the bactericidal power of whole, defibrinated blood with that of washed cells. The cells were washed 4 times in sterile, physiological saline, as described under "Methods." It is plain from this experiment that the suspension of cells alone was not capable of killing the gonococcus. When the cells were removed from the tubes, and smears were made and stained, it was noted that active phagocytosis had taken place. There was, however, no indication that bacterial growth had been suppressed.

TABLE $V$

Comparison of bactericidal power of whole defibrinated blood with that of washed cells suspended in saline *

\begin{tabular}{|c|c|c|c|c|c|c|c|c|c|c|c|c|c|c|}
\hline \multirow{2}{*}{$\begin{array}{l}\text { Obser- } \\
\text { vation } \\
\text { number }\end{array}$} & \multicolumn{7}{|c|}{ Whole defibrinated blood } & \multicolumn{7}{|c|}{ Washed cells in saline } \\
\hline & $10^{-1}$ & $10-2$ & $10^{-8}$ & $10^{-1}$ & $10^{-6}$ & $10^{-6}$ & $10^{-1}$ & $10^{-1}$ & $10^{-2}$ & $10^{-3}$ & $10^{-4}$ & $10^{-\infty}$ & $10^{-6}$ & $10^{-7}$ \\
\hline $\begin{array}{l}1 \\
2 \\
3 \\
4 \dagger \\
5\end{array}$ & $\begin{array}{l}0 \\
+ \\
0 \\
0 \\
+\end{array}$ & $\begin{array}{l}0 \\
0 \\
0 \\
0 \\
+\end{array}$ & $\begin{array}{l}0 \\
0 \\
0 \\
0 \\
+\end{array}$ & $\begin{array}{l}0 \\
0 \\
0 \\
0 \\
+\end{array}$ & $\begin{array}{l}0 \\
0 \\
0 \\
0 \\
0\end{array}$ & $\begin{array}{l}0 \\
0 \\
0 \\
0 \\
0\end{array}$ & $\begin{array}{l}0 \\
0 \\
0 \\
0 \\
0\end{array}$ & $\begin{array}{l}+ \\
+ \\
+ \\
+\end{array}$ & $\begin{array}{l}+ \\
+ \\
+ \\
+\end{array}$ & $\begin{array}{l}+ \\
+ \\
+\end{array}$ & $\begin{array}{l}+ \\
+ \\
+ \\
+\end{array}$ & $\begin{array}{l}+ \\
+ \\
+ \\
0 \\
+\end{array}$ & $\begin{array}{l}+ \\
+ \\
+ \\
0 \\
+\end{array}$ & $\begin{array}{l}0 \\
+ \\
0 \\
0 \\
+\end{array}$ \\
\hline
\end{tabular}

$*+=$ growth.

$0=$ no growth.

$\uparrow$ No organisms were present in 6 and 7 dilutions.

$A$ comparison of phagocytosis in specimens of blood with and without bactericidal power

To supplement the above observations on phagocytosis and the rôle of the polymorphonuclear cells in killing the gonococcus, the degree of phagocytosis was studied in several cases. As has been related in the bactericidal studies of the whole blood, there was evidence that the gonococcus was killed by lysis and not by intracellular digestion. When the killing was complete, it was not possible to find any organisms within or outside the cells. Inasmuch as it was not possible to demonstrate organisms when they were killed, the possibility of intracellular digestion was not absolutely excluded. The experiment with cells alone demonstrated that the organisms were engulfed by the leukocytes but growth was not suppressed, so that it seemed unlikely that the cells actually killed them independently. It was of interest, however, to determine whether there was 
TABLE VI

Comparison of bactericidal power and phagocytic activity of whole blood and washed cells from normal people and patients with gonococcal arthritis *

\begin{tabular}{|c|c|c|c|c|c|c|c|c|c|c|c|c|c|c|c|c|c|c|}
\hline \multirow{2}{*}{ Observation } & \multicolumn{7}{|c|}{$\begin{array}{l}\text { Killing power } \\
\text { whole defibrinated blood }\end{array}$} & \multicolumn{2}{|c|}{$\begin{array}{l}\text { Phagocytosis whole } \\
\text { defibrinated blood. } \\
50 \text { polys counted }\end{array}$} & \multicolumn{7}{|c|}{$\begin{array}{l}\text { Killing power } \\
\text { cells washed in saline }\end{array}$} & \multicolumn{2}{|c|}{$\begin{array}{l}\text { Phagocytosis cells } \\
\text { washed in saline. } \\
50 \text { polys counted }\end{array}$} \\
\hline & $10^{-1}$ & $10^{-2}$ & $10^{-3}$ & $10^{-1}$ & $10^{-8}$ & $10^{-6}$ & $10^{-7}$ & $\begin{array}{c}\text { With } \\
\text { organisms }\end{array}$ & $\begin{array}{l}\text { Without } \\
\text { organisms }\end{array}$ & $10^{-1}$ & $10^{-3}$ & $10^{-8}$ & $10^{-4}$ & $10^{-6}$ & $10^{--6} \mid$ & $10^{-7}$ & $\begin{array}{c}\text { With } \\
\text { organisms }\end{array}$ & $\begin{array}{l}\text { Without } \\
\text { organisms }\end{array}$ \\
\hline $\begin{array}{l}\text { Patient } 1 \ldots \ldots \ldots \\
\text { Control } 1 \ldots \ldots \ldots \\
\text { Patient } 2 \ldots \ldots \ldots \\
\text { Control } 2 \ldots \ldots \ldots\end{array}$ & $\begin{array}{l}+ \\
0 \\
+ \\
+\end{array}$ & $\begin{array}{l}+ \\
0 \\
+ \\
+\end{array}$ & $\begin{array}{l}+ \\
0 \\
+ \\
0\end{array}$ & $\begin{array}{l}0 \\
0 \\
+ \\
0\end{array}$ & $\begin{array}{l}0 \\
0 \\
+ \\
0\end{array}$ & $\begin{array}{l}0 \\
0 \\
+ \\
0\end{array}$ & $\begin{array}{l}0 \\
0 \\
+ \\
0\end{array}$ & $\begin{array}{l}40 \\
50 \\
33 \\
30\end{array}$ & $\begin{array}{r}10 \\
0 \\
17 \\
20\end{array}$ & $\stackrel{+}{+}$ & + & $\stackrel{+}{+}$ & + & $\stackrel{+}{+}$ & $\stackrel{+}{+}$ & $\begin{array}{l}\mathbf{0} \\
\mathbf{0}\end{array}$ & $\begin{array}{l}49 \\
45\end{array}$ & $\frac{1}{5}$ \\
\hline
\end{tabular}

$+=$ growth.

$0=$ no growth.

any difference in the opsonic index of patients with good bactericidal power and those with a low titer.

Table VI illustrates the killing power and the phagocytic activity of the whole defibrinated blood of patients with gonococcal infections as compared with the results obtained with the blood of normal controls. It is to be noted that there is no correlation between the bactericidal power and phagocytic activity of the whole blood. The same table also shows the absence of killing power of cells washed in saline; a majority of the cells, however, engulfed organisms. Table VII gives a comparison of the killing power of whole defibrinated blood of normal controls with the degree of phagocytosis present.

It may be taken as established, then, that the opsonic index is no indication of the bactericidal power of a patient's blood. Phagocytosis occurs without killing, and the death of the bacteria can be accomplished without cells.

\section{The bactericidal effect of polyvalent antigonococ- cal horse serum when added to whole defibri- nated blood of patients with gonococcal infection}

To determine whether the bacteriolytic power of the whole blood could be enhanced by the addition of immune serum, the following experiment was done. A polyvalent antigonococcal horse serum that agglutinated all strains of the gonococcus that we studied was added to the whole defibrinated blood of a patient with gonococcal arthritis. Table VIII illustrates the effect of adding $0.1 \mathrm{cc}$. of a $1: 10$ and $1: 40$ dilution of this serum to 0.5 cc. of defibrinated blood of Patient C. The " C"
TABLE VII

Comparison of the killing power with the phagocytic activity of whole defibrinated blood of normal controls *

\begin{tabular}{|c|c|c|c|c|c|c|c|c|c|}
\hline \multirow{2}{*}{$\begin{array}{l}\text { Obser- } \\
\text { vation } \\
\text { num- } \\
\text { ber }\end{array}$} & \multicolumn{7}{|c|}{ Killing power whole blood } & \multicolumn{2}{|c|}{$\begin{array}{l}\text { Phagocytosis } 50 \\
\text { polys counted }\end{array}$} \\
\hline & $10^{-1}$ & $10^{-2}$ & $10^{-8}$ & $10^{-4}$ & $10^{-6}$ & $10^{-6}$ & $10^{-7}$ & $\begin{array}{c}\text { With } \\
\text { organ- } \\
\text { isms }\end{array}$ & $\begin{array}{l}\text { With- } \\
\text { out } \\
\text { organ- } \\
\text { igms }\end{array}$ \\
\hline $\begin{array}{l}1 \\
2 \\
3 \\
4 \\
5 \\
6\end{array}$ & $\begin{array}{l}+ \\
+ \\
+ \\
+\end{array}$ & $\begin{array}{l}+ \\
+ \\
+ \\
+\end{array}$ & $\begin{array}{l}+ \\
+ \\
+ \\
+\end{array}$ & $\begin{array}{l}0 \\
+ \\
+ \\
+ \\
+ \\
+\end{array}$ & $\begin{array}{l}0 \\
+ \\
+ \\
+ \\
0 \\
0\end{array}$ & $\begin{array}{l}0 \\
+ \\
+ \\
+ \\
0 \\
0\end{array}$ & $\begin{array}{l}0 \\
+ \\
0 \\
0 \\
0 \\
0\end{array}$ & $\begin{array}{l}40 \\
46 \\
37 \\
35 \\
44 \\
43\end{array}$ & $\begin{array}{r}10 \\
4 \\
13 \\
15 \\
6 \\
7\end{array}$ \\
\hline
\end{tabular}

$*+=$ growth.

$0=$ no growth.

strain of gonococcus was obtained from this patient, and it is seen that $0.5 \mathrm{cc}$. of his blood was capable of killing only 7 organisms. Adding the above dilutions of immune serum to his blood greatly increased the killing power. This procedure was repeated successfully several times using

TABLE VIII

Bactericidal power of whole defibrinated blood and that of the same blood to which small amounts of gonococcal immune serum had been added *

\begin{tabular}{|c|c|c|c|}
\hline $\begin{array}{l}\text { Number of colonies } \\
\text { "C" strain }\end{array}$ & $\begin{array}{c}\text { Whole } \\
\text { defibrinated } \\
\text { blood of } \\
\text { Patient "C" }\end{array}$ & $\begin{array}{l}\text { Whole defibri- } \\
\text { nated blood } \\
+0.1 \mathrm{cc} . \\
\text { 1:10 immune } \\
\text { serum }\end{array}$ & $\begin{array}{c}\text { Whole defibri- } \\
\text { nated blood } \\
+0.1 \text { cc. } \\
\text { 1:40 immune } \\
\text { gerum }\end{array}$ \\
\hline $\begin{array}{r}700,000 \ldots \ldots \\
70,000 \ldots \ldots \\
7,000 \ldots \ldots \\
700 \ldots \ldots \\
70 \ldots \ldots \\
7 \ldots \ldots \\
7 \ldots \ldots \\
7 \ldots\end{array}$ & $\begin{array}{l}+ \\
+ \\
+ \\
+ \\
+ \\
0\end{array}$ & $\begin{array}{l}+ \\
+ \\
0 \\
0 \\
0 \\
0\end{array}$ & $\begin{array}{l}+ \\
\mathbf{0} \\
\mathbf{0} \\
\mathbf{0} \\
\mathbf{0} \\
\mathbf{0}\end{array}$ \\
\hline
\end{tabular}

$*+=$ growth

$0=$ no growth. 
the blood of both normals and patients with gonococcal infections. The antigonococcal horse serum did not contain complement and, therefore, had little or no killing power. Its bactericidal action depended upon the addition of fresh serum containing complement.

The bactericidal effect of whole defibrinated blood of patients before and after the intravenous administration of polyvalent antigonococcal horse serum

As related above, it was found that when polyvalent, antigonococcal horse serum was added to whole defibrinated blood in vitro, the bactericidal power of the blood was greatly increased. We then proceeded to administer the serum intra- chart, were similar to those shown in the figure. When $0.1 \mathrm{cc}$. of a $1: 10$ and $1: 40$ dilution of serum was added to the patient's blood in vitro, the killing power was increased. By calculation it was found that if $0.1 \mathrm{cc}$. of a 1:40 dilution of immune serum added to $0.5 \mathrm{cc}$. of his blood killed all the organisms except those in the first dilution, approximately 25 cc. of undiluted serum would have to be administered intravenously to produce the same effect in vivo. Accordingly, $25 \mathrm{cc}$. of polyvalent, antigonococcal horse serum were administered intravenously without reaction. Four hours later, a bactericidal test showed an increase of the killing power of the patient's blood. Twenty-four hours later, the killing power had reached the same level as that found when the

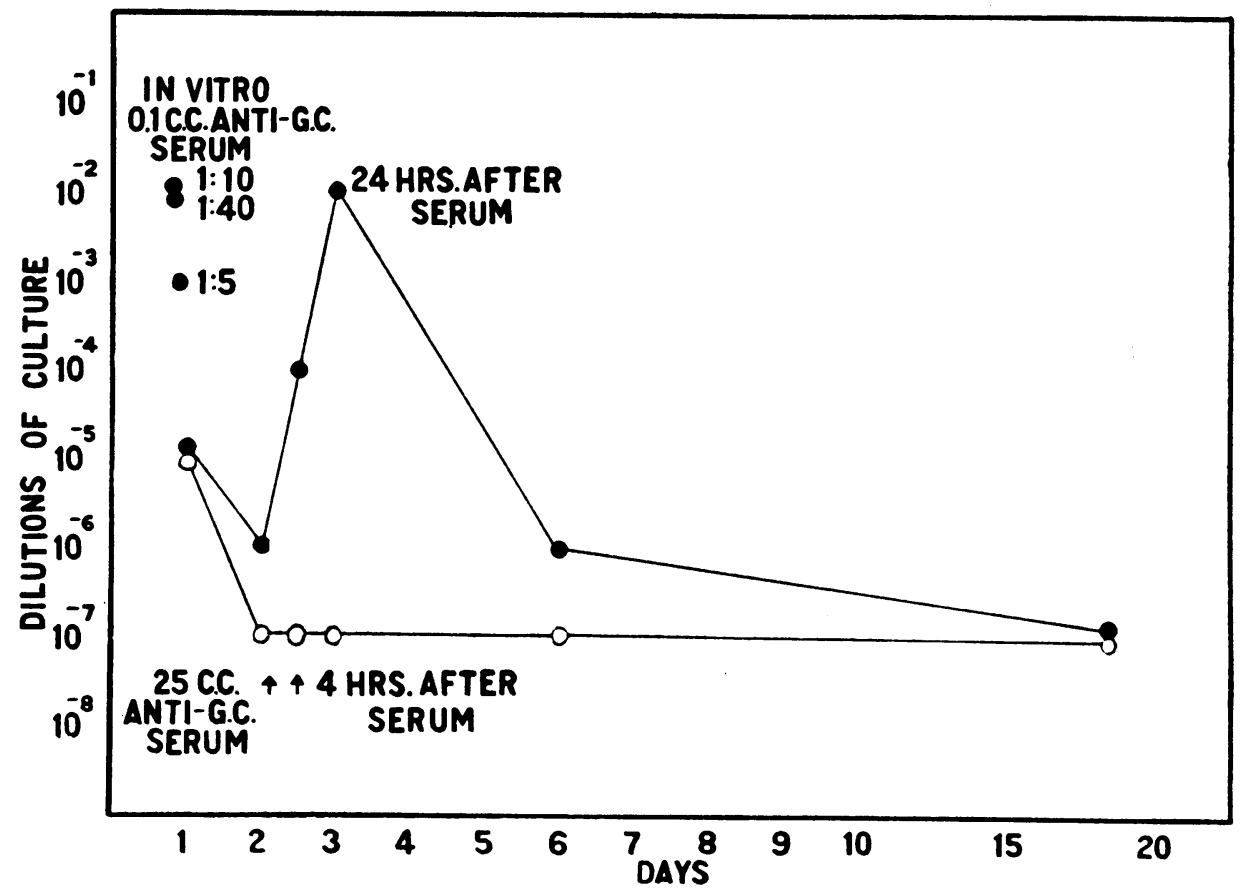

Fig. 1. The Bacteriolytic Power of the Whole Blood Following the Addition of IMMUNe SERUM in vitro AND in vivo.

venously to a patient for the purpose of determining whether the same effect could be obtained in vivo. The patient was recovering from an attack of acute gonococcal arthritis. The strain of gonococcus was obtained from his prostatic discharge. In Figure 1, it is seen that the killing power of the patient's blood was essentially the same as that of a normal control. The results of several other control tests, not included on the equivalent amount of serum was added in vitro. This maximum bactericidal action was of short duration, however, and 5 days after receiving the serum, the killing power of his blood had returned to the level observed before injection.

An opportunity arose for a practical demonstration of the value of immune gonococcal serum in a patient with gonococcal septicemia. The focus of his infection was a chronic prostatitis; he did 
not have an endocarditis. His illness was further complicated by cirrhosis of the liver with jaundice and ascites, and a hemorrhagic eruption of the whole body due to a thrombocytopenia. Before the administration of immune serum, gonococci were cultured from his circulating blood, and the killing power of his blood was less than that of the normal control. Immune serum was then administered intravenously, and the following day his blood was sterile, and there was an increase in the titer of antibodies in the blood. On the basis of the preceding observation that this increase in bactericidal power resulting from serum treatment may be of only short duration, daily injections of serum were administered. The patient's blood continued to show excellent killing power. From these results, it seems obvious that the bactericidal power of the blood can be enhanced in vivo and in vitro by the addition of antigonococcal immune serum. The therapeutic significance of these observations will be discussed in a subsequent paper.

\section{DISCUSSION}

From the evidence that we have presented, there can be little doubt that whole blood from most patients with gonococcal infection is bactericidal for the gonococcus. This property is a function of the plasma or serum and it produces its action by means of lysis. Bacteriolysin and complement are necessary for this mechanism of destruction. There was no evidence that the polymorphonuclear leukocytes were able to kill gonococci in vitro. This was the case, in spite of the fact that active phagocytosis could be demonstrated. In this respect, it would appear that the mechanism for the destruction of the gonococcus is similar to that of other gram-negative organisms. Ward and Wright (2) in a similar study of the $B$. influenzae state, " Generally speaking, the gram-positive organisms are first sensitized by the antibody in the serum and then phagocyted by the leukocytes, no organisms being killed in the absence of the cells; but with the gramnegative organisms, the cells play a very minor rôle, the bacteria being sensitized by the antibody and then killed by the complement. Under certain conditions the sensitized organisms are not only killed, but undergo lysis. $B$. influenzae falls into this category." Topley (3) is of the same opinion in regard to such organisms as the cholera vibrio, the typhoid bacillus, and "most gramnegative organisms." In an immunological study of the meningococcus, which is closely related to the gonococcus, Silverthorne and Fraser $(4,5)$ concluded that the plasma of human blood, and not the cells, killed the meningococcus. The earlier work of Torrey (6) is of considerable significance in relation to immunological studies done on guinea pigs inoculated with gonococci. $\mathrm{He}$ concluded that phagocytosis played little part in the destruction of gonococci, since the degree of phagocytosis was apparently the same whether the animal died or recovered. Torrey believed that the rapid destruction of gonococci in the blood was due to specific bactericidal bodies. Further important observations were made by Martin (7) in studying the bactericidal action of an animal's blood upon the gonococcus; he stated that complemented immune serum was most important in the destruction of gonococci.

Although the circulating leukocytes, particularly the polymorphonuclear leukocytes, do not appear to play an important part in killing the gonococcus, it would be desirable to know more concerning the tissue cells and their action on the gonococcus. Torrey (6) studied the phagocytic activity of cells in peritoneal exudates and of the omentum in guinea pigs injected intraperitoneally with gonococci. He stated that macrophages in the peritoneal exudate ingested gonococci with much greater avidity than did the polymorphonuclear leukocytes on the surface of the omentum. But the degree of phagocytosis was the same whether the animal died or recovered.

Our information concerning the significance of tissue reactions in the prevention of spread in gonococcal infections is very meager. An early reaction to infections of the urethra is a profuse exudate consisting mostly of polymorphonuclear leukocytes. What action do these cells have on the organism, especially those containing intracellular gonococci? If the organisms are not killed when ingested by the leukocytes, it might be postulated that this phagocytosis is an attempt to localize the gonococci and prevent their dissemination throughout the tissues. Further immunological studies are necessary before a proper eval- 
uation can be made concerning the rôle of the tissue cells and those found in exudates in protecting the body against widespread invasion by gonococci.

\section{SUMMARY}

1. A study of the bactericidal action of whole defibrinated blood on several strains of gonococci justifies the following conclusions.

a. Human defibrinated whole blood has the property of killing gonococci by means of lysis.

$b$. This bactericidal factor resides in serum or plasma, and is dependent upon the presence of complement.

c. Heated serum or plasma, or immune serum without complement, have little or no bactericidal power.

$d$. Freshly washed leukocytes suspended in saline have little or no killing action, though the polymorphonuclear leukocytes actively phagocyte the organisms.

$e$. There does not appear to be any relationship between the degree of phagocytosis and the bactericidal power of blood.

2. The addition of polyvalent, antigonococcal horse serum to human blood greatly increases the killing power.
3. The intravenous administration of immune serum to patients greatly increases the killing power of their blood.

We acknowledge our thanks to Miss Marjorie L. Jewell and Miss Eleanor M. Fleming for technical assistance.

\section{BIBLIOGRAPHY}

1. Spink, W. W., and Keefer, C. S., Studies of hemolytic streptococcal infection. II. The serological reactions of the blood during erysipelas. J. Clin. Invest., 1936, 15, 21.

2. Ward, H. K., and Wright, J., Studies on influenzal meningitis. I. The problems of specific therapy. J. Exper. Med., 1932, 55, 223.

3. Topley, W. W. C., An Outline of Immunity. William Wood and Co., Baltimore, 1933, p. 73.

4. Silverthorne, N., and Fraser, D. T., The action of human blood on the meningococcus. Brit. J. Exper. Path., 1934, 15, 362.

5. Silverthorne, N., and Fraser, D. T., Observations on the action of human and animal blood on the meningococcus. J. Immunol., 1935, 29, 523.

6. Torrey, J. C., A study of natural and acquired immunity of guinea pigs to gonococcus. J. Med. Research, 1908, 18, 347.

7. Martin, W. B. M., The isolation of the gonococcus and its differentiation from allied organisms. J. Path. and Bact., 1910-11, 15, 76. 